\title{
Allergy-immunology glossary
}

\section{Zeinab A. El-Sayed, Rasha H. El-Owaidy}

Pediatric Allergy and Immunology Unit, Children's Hospital, Ain-Shams University

Towards a clear designation of some of the terms used in allergology and immunology.

\begin{tabular}{|c|c|c|}
\hline $\begin{array}{l}\text { Hemophagocytic } \\
\text { syndrome }\end{array}$ & $\begin{array}{l}\text { Hemophagocytic syndrome also known as } \\
\text { hemophagocytic lymphohistiocytosis, is an } \\
\text { uncommon, life-threatening, hyperinflammatory } \\
\text { immunological disorder that is characterized by } \\
\text { prolonged high fever, hyperlipidemia, } \\
\text { hepatosplenomegaly and hemophagocytosis of } \\
\text { bone marrow cells. It results from defective } \\
\text { function of natural killer cells and cytotoxic T } \\
\text { lymphocytes with failure of killing of the infected } \\
\text { antigen presenting cells leading to ongoing } \\
\text { immune activation, hypercytokinemia and organ } \\
\text { damage. }\end{array}$ & الدموية بلعة الكريات \\
\hline $\begin{array}{l}\text { Alpha beta double } \\
\text { negative T cell }\end{array}$ & $\begin{array}{l}\text { Alpha beta double negative } \mathrm{T} \text { cells } \\
\left(\mathrm{CD} 3^{+} \mathrm{CD} 4^{-} \mathrm{CD} 8^{-} \alpha \beta \mathrm{DN} \mathrm{T} \text { cells) comprise a small }\right. \\
\text { subset of mature peripheral T cells that normally } \\
\text { do not exceed } 2 \% \text { of } \mathrm{T} \text { cells. Both regulatory and } \\
\text { pathogenic functions have been attributed to } \alpha \beta \\
\mathrm{DN} \mathrm{T} \text { cells. The expansion of these cells in } \\
\text { peripheral blood and lymphoid tissues of patients } \\
\text { with autoimmune lymphoproliferative syndrome } \\
\text { (ALPS) is a consistent feature and is one of the } \\
\text { diagnostic criteria of ALPS. }\end{array}$ & مزدوجة السلبياة التائية الفا بيتا \\
\hline PRAM score & $\begin{array}{l}\text { Pediatric Respiratory Assessment Measure: It is a } \\
\text { 12-point validated clinical scoring tool used to } \\
\text { classify the severity of asthma exacerbations and } \\
\text { its response to treatment. It is based on using a } \\
\text { combination of scalene muscle contraction, } \\
\text { suprasternal retractions, wheezing, air entry and } \\
\text { oxygen saturation. }{ }^{4}\end{array}$ & التنفسي للأطفار التقيم \\
\hline
\end{tabular}

\section{REFERENCES}

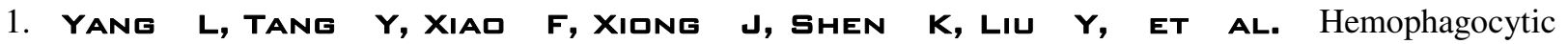
lymphohistocytosis in the Chinese Han population may be associated with an STXBP2 Gene Polymorphism. PLoS ONE 2016;11(8): e0159454.

$$
\begin{aligned}
& \text { r. المعجم الطبي الموحد (انجليزي، عربي، فرنسي) مجلس وزراء الصحة العرب، المنظمة العالمية للصحة، اتحاد أطباء العرب، }
\end{aligned}
$$

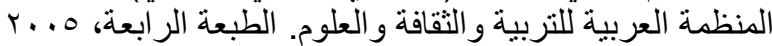

3. martina mN, Noel S, saxena A, Rabb h, hamad aA. Double negative (DN) $\alpha \beta$ T cells: misperception and overdue recognition. Immunol Cell Biol 2015; 93(3):305-10.

4. Ducharme fM, chalut D, Plotnick l, Savdie C, Kudirka D, Zhang X, et al. The Pediatric Respiratory Assessment Measure: a valid clinical score for assessing acute asthma severity from toddlers to teenagers. J Pediatr. 2008;152(4):476-80, 480.e1 